\title{
Estudo Histológico dos Enxertos Ósseos Homólogos Humanos.
}

\author{
A Histological Study of Human Allografts
}

\author{
André Donato Baptista ${ }^{1}$, Andrey Sorrillha ${ }^{1}$, Túllo Augusto de Medeiros Tormes ${ }^{1}$, Yussef Ali Abdoune ${ }^{1}$, \\ Alberto Tesconi Crocl ${ }^{2}$, Olavo Pires de Camargo ${ }^{3}$, Claudia Regina G. C. M. de Oliveira ${ }^{4}$
}

\section{RESUMO}

Devido ao crescente uso dos enxertos homólogos humanos (aloenxertos) nas cirurgias ortopédicas reconstrutivas, há a necessidade do completo conhecimento de suas características biomecânicas e histológicas. Este estudo compara, quanto às características histológicas, os enxertos de cadáver colhidos de côndilo femoral a fresco, aos criopreservados a menos $80^{\circ} \mathrm{C}$ por trinta dias.

São comparados vinte espécimes em cada grupo, quanto aos seguintes parâmetros histológicos: viabilidade celular, presença de vascularização, necrose, manutenção da matriz óssea, processo inflamatório, remodelação óssea e fibrose.

Após análise estatística utilizando o método de Fisher $(\mathrm{p} \leq 0,05)$, o estudo conclui que apenas a viabilidade celular apresenta mudança significativa após a criopreservação.

Os enxertos ósseos não necessitam de células viáveis para sua utilização. Logo, o processo de criopreservação é um método útil para o armazenamento dos aloenxertos em bancos de tecidos não inviabilizando seu emprego futuro nas cirurgias ortopédicas.

Descritores: Aloenxerto; Histologia; Criopreservação.

\section{INTRODUÇÃO}

Os enxertos de ossos autólogos, homólogos e sintéticos têm desempenhado importante papel na cirurgia ortopédica reconstrutiva há algum tempo. Conhecer as características biológicas e biomecânicas destes materiais é de suma importância para seu emprego adequado(3,7,10,12).

Os enxertos autólogos, embora tenham propriedades biológicas ideais na maioria dos casos, apresentam limitação quanto à quantidade possível de ser retirada, principalmente em situações que requeiram um grande volume de enxerto, como

\section{SUMMARY}

Due to the increasing use of the human allografts in the reconstructive orthopedic surgeries, the complete knowledge of its biomechanics and hystologics characteristic is needed. This study compared allografs picked of femoral condilar from cool air cadavers and after cryopreservation (under $-80^{\circ} \mathrm{C}$ ) for thirty days with relationship to the hystologic's characteristic.

Twenty specimens were compared in each group, with relationship to the following hystologic's parameters: cellular viability, vascularization presence, necrosis, and maintenance of the bony matrix, inflammatory process, bony remodelation and fibrosis.

After statistical analysis using the Fisher's method( $p \leq 0,05)$, the study concluded that only the cellular viability had significant change after the cryopreservation.

The bony grafts don't need viable cells for being used, so the cryopreservation process is an useful method for the allografts's tissue bank storage, not making unfeasible its future employment in orthopedic surgeries.

Key words: Allograft; Histology; Cryopreservation.

\section{INTRODUCTION}

Autologous, homologous, and synthetic grafts play an important role in reconstructive orthopedic surgery for some time now. In order to employ them properly, it is fundamental to know the biological and biomechanical characteristics of such materials $(3,7,10,12)$

Although in most cases allografts have optimal biological properties, they show certain limitations as to the possible amount to be removed, mainly in situations requiring a large graft volume, such as in hip revision arthroplasties and reconstructive on-
Trabalho realizado no Instituto de Ortopedia e Traumatologia do Hospital das Clínicas da Faculdade de Medicina da Universidade de São Paulo - São Paulo - SP.

1 - Residente do IOTHCFMUSP

2 - Professor Associado da FMUSP, Chefe do Grupo de Artroplastias e do Banco de Tecidos do IOTHCFMUSP.

3 - Professor Associado da FMUSP, Chefe da Disciplina de Ortopedia Geriátrica,

Oncológica e Reconstrutiva.

4 - Chefe do Serviço de Anatomia Patológica do IOTHCFMUSP.

Endereço para correspondência: Rua Ovídio Pires de Campos 333, Banco de Tecidos do IOTHCFMUSP, $1^{\circ}$. Andar CEP 05403-010 - São Paulo - SP E.mail: croci@usp.br.

Trabalho recebido em 21/05/2003. Aprovado em 25/07/2003
Work Performed at School of Medicine of University Sao Paulo, Tissue Bank - Sao Paulo - SP - Brazil.

1 - Resident - IOTHCFMUSP

2 - Associate Professor, FMUSP, Head of Artroplastly Group and Tissue Bank IOTHCFMUSP.

3 - Associate Professor FMUSP, Head of Geriatric, Oncological and Reconstructive Orthopedics - IOTHCFMUSP.

4 - Head of Patology's Service - IOTHCFMUSP.

Address: Rua Ovídio Pires de Campos 333, Banco de Tecidos do IOTHCFMUSP, $1^{\circ}$ Andar CEP 05403-010 - São Paulo - SP - E.mail: croci@usp.br. 
nas revisões de artroplastias de quadril e cirurgias oncológicas reconstrutivas. Os substitutos ósseos (hidroxiapatita, sulfato de cálcio, etc.) encontram-se em fase experimental, quanto às suas propriedades biomecânicas, de osteointegração e osteoindução, não sendo ainda uma alternativa definitiva ${ }^{(1)}$.

Logo, o enxerto homólogo (aloenxerto) surge como boa opção. Após o advento dos bancos de tecidos, ampliação e melhora das técnicas de preservação, aumentaram as disponibilidades dos aloenxertos, o que vem de encontro às diversas necessidades ortopédicas ${ }^{(6,14)}$.

Por ser preparado previamente ao procedimento da enxertia, o aloenxerto contribui de forma relevante na redução da morbidade cirúrgica e melhoria dos resultados finais, devido à redução do tempo cirúrgico e de isquemia (quando se utiliza o torniquete).

As desvantagens dos aloenxertos envolvem o risco da transmissão de doenças e o potencial de antigenicidade, complicações estas que podem ser controladas por meio dos métodos de congelamento e armazenamento. O risco infeccioso pode ser diminuído por meio de testes sorológicos dos doadores, descarte de material que produza cultura bacteriológica positiva, manipulação do enxerto sob condições assépticas e esterilização, seja por radiação ou óxido de etileno ${ }^{(2,5,6,11)}$.

O potencial imunogênico altera-se conforme o preparo recebido pelos enxertos. Os enxertos frescos causam reações imunes inaceitáveis à sua aplicação clínica. O congelamento destes diminui de forma considerável esta resposta imune do hospedeiro, preservando as propriedades biomecânicas e osteoindutivas do enxerto. A associação de congelamento e desidratação, como na liofilização, diminui ainda mais a resposta imune, porém às custas de alterações biomecânicas indesejáveis $^{(2,4,8,9,15)}$.

Em nosso serviço o método de armazenamento é realizado pela criopreservação a menos $80^{\circ} \mathrm{C}$, sendo o processamento realizado sob assepsia.

Alguns estudos mostram que a análise histológica do tecido captado é um passo imprescindível na seleção dos enxertos, visto que, mesmo sem história clínica prévia, os exames laboratoriais apontaram até $8 \%$ de achados histopatológicos de relevância que podem contra-indicar sua utilização. Dentre os achados estão: a condrocalcinose, a necrose avascular, o osteoma, o linfoma, o condrossarcoma e a doença de Paget ${ }^{(13)}$.

\section{OBJETIVOS}

O objetivo deste estudo é analisar comparativamente as alterações histológicas do aloenxerto de fêmur distal de cadáver humano, após criopreservação a menos $80^{\circ} \mathrm{C}$, em relação a um grupo controle conservado a $4^{\circ} \mathrm{C}$.

\section{MATERIAL E MÉTODO}

Foram estudados 40 enxertos de fêmur distal, retirados de 20 cadáveres com idades entre 20 e 40 anos, sendo 20 fêmures direitos e 20 esquerdos, provenientes do Serviço de Verificação de Óbitos (SVO). Os cadáveres foram os não reclamados no SVO, mantidos por 48 horas a $4^{\circ} \mathrm{C}$.

Os enxertos foram retirados através de pequena incisão sobre o côndilo femoral lateral, com uma trefina de um centímetro cological surgeries. Bone substitutes (such as hydroxyapatite, calcium sulfate, and others) are not yet definite alternatives, since their biomechanical features and their osteointegration and osteoinduction properties are still subject to experimental verification ${ }^{(1)}$.

Therefore, the homologous graft (allograft) emerges as a good option. The advent of tissue banks and the higher variety and improvement of preservation techniques increased the availability of allografts, which greatly benefits the various orthopedic needs ${ }^{(6,14)}$.

Since they are prepared previously to the grafting process, allografts make an important contribution in the reduction of surgical morbidity and the improvement of outcomes, due to the reduction in surgical time and ischemia (when a tourniquet is employed).

Allografts have the disadvantage of involving complications such as the risk of transmitting diseases, plus an antigenicity potential, although this may be controlled by freezing and storage methods. The infection risk may be reduced by serologically testing the donators, discarding any material that might produce positive bacteriological culture, and handling the grafts under aseptic conditions or by sterilization using either radiation or ethylene oxide ${ }^{(2,5,6,11)}$.

The immunogenic potential changes according to the method used to prepare the grafts. Fresh grafts will cause immune reactions that are unacceptable to their clinical application. Graft freezing decreases significantly this immune response from the host, since it preserves the biomechanical and osteoinductive properties of the graft. Similarly to lyophilization, the association of freezing and dehydration reduces the immune response even more, although at the expense of adverse biomechanical changes $^{(2,4,8,9,15)}$

In our Service, the storage method consists of cryopreserving the material at minus $80^{\circ} \mathrm{C}$, with the processing being performed under aseptic conditions.

Several studies have shown that histological analysis of the collected tissue is a pivotal step in the selection of grafts, since that, even with no previous clinical history, laboratory tests indicated as much as $8 \%$ of relevant histopatologic findings that might contraindicate its use. Such findings include chondrocalcinosis, avascular necrosis, osteoma, lymphoma, chondrosarcoma and Paget's disease ${ }^{(13)}$.

\section{OBJECTIVES}

The objective of this study is to comparatively analyze histological changes found in distal femur allografts of human cadavers after cryopreservation at minus $80^{\circ} \mathrm{C}$ versus a control group kept at $4^{\circ} \mathrm{C}$.

\section{MATERIAL AND METHOD}

We studied 40 distal femur grafts taken from 20 cadavers in the 20-40 years age group; 20 were right femurs and 20 were left femurs provided by the Death Verification Service (Serviço de Verificação de Óbitos, SVO). All cadavers were unclaimed corpses maintained at the SVO at $4{ }^{\circ} \mathrm{C}$ for 48 hours.

The grafts were withdrawn through a small incision made on 
de diâmetro, a dois centímetros de distância da superfície articular. Após identificação, as peças foram envoltas em compressas umedecidas em solução fisiológica e embaladas em sacos plásticos para transporte do SVO até o Laboratório de Anatomia Patológica e ao Banco de Tecidos.

Das 40 peças obtidas, 20 foram destinadas ao estudo histológico imediato (grupo A) e as restantes (Grupo B) foram enviadas ao Banco de Tecidos para a criopreservação. Cada cadáver tem sempre uma peça em cada um dos Grupos, e os lados direito e esquerdo foram divididos de maneira alternada. As 20 peças do Grupo B, destinadas ao Banco de Tecidos, foram acondicionadas em embalagens seladas de polietileno de $0,5 \mu \mathrm{m}$, com tripla proteção e mantidas sob congelamento a menos $80^{\circ}$ C em freezer vertical elétrico modelo SANYO MDF U3086S, com backup de $\mathrm{CO}^{2}$, controle de manutenção de temperatura por monitoração gráfica e válvula de alarme interior, conectado a sistema de alarme externo para temperaturas superiores a menos $40^{\circ} \mathrm{C}$ e mantidas sob estas condições por 30 dias.

Todos os espécimes foram analisados no Serviço de Anatomia Patológica de nosso Departamento.

A preparação de cada uma das peças seguiu a seguinte metodologia:

1) Fixação em formol a 10\% por 24 horas.

2) Descalcificação em ácido nítrico a 7,5\% por 24 horas.

3) Processamento tecidual em aparelho histotécnico.

4) Três cortes histológicos de cada amostra.

5) Coloração pelo método de hematoxilina-eosina.

A microscopia analisou a quantidade de osteoclastos, osteoblastos, estroma vascular e a presença de osso imaturo e lamelar. Esta análise permitiu avaliar os seguintes critérios: viabilidade celular, vascularização, necrose, manutenção da matriz óssea, processo inflamatório, remodelação óssea e presença de fibrose.

Foram comparados estatisticamente através do teste de $\mathrm{Fi}$ sher os resultados obtidos, qualitativa e quantitativamente, dos Grupos A e B. Consideramos significativos aqueles com índice de significância $p<0,05$.

\section{RESULTADOS}

Dos 40 espécimes avaliados, 20 do Grupo controle (Grupo A) e 20 criopreservados (Grupo B), obtivemos os resultados que se seguem:

Quanto à viabilidade celular, o Grupo controle (A) teve 100\% de manutenção da mesma (20/20). Já o grupo submetido ao congelamento apresentou 70\% de viabilidade (14 das 20 espécimes avaliadas). Pelo método de Fisher isso nos dá $p=0.02$, ou seja, há diferença significativa entre os dois Grupos.

Já em relação ao item vascularização, o Grupo controle obteve $100 \%$ de positividade e o grupo criopreservado $85 \%$. Assim temos, pelo método de Fisher, $p=0.231$, não havendo diferença significativa neste item.

Em outra análise, a necrose esteve presente em 100\% dos espécimes, de ambos os Grupos. Ocorreu assim, pelo método de Fisher, $p=1$, não havendo diferença significativa.

Analisando a manutenção de matriz óssea, dos 40 espécimes avaliados, em 34 houve preservação da mesma, sendo 19 the lateral femoral condylus using a 1-cm diameter circular saw, two centimeters away from the joint surface. The pieces were identified, wrapped in saline-wetted bandages, and then packed in plastic bags to be transported from the SVO to the Laboratory of Pathological Anatomy and the Tissue Bank.

Twenty of the 40 pieces obtained were assigned to immediate histological investigation (Group A) while the others (Group B) were sent to the Tissue Bank to be cryopreserved. A piece of each cadaver was always included in each group, and the right and left sides were alternately divided. The 20 pieces included in Group B to be sent to the Tissue Bank were packed in sealed 0.5- $\mu \mathrm{m}$ thick polyethylene bags provided with triple protection and kept frozen at minus $80^{\circ} \mathrm{C}$ in a SANYO MDF U3086S electric vertical freezer with $\mathrm{CO}_{2}$ backup, temperature maintenance control by graphic monitoring and an inside alarm valve connected to an external system for temperatures above minus $40^{\circ} \mathrm{C}$, and kept under such conditions for 30 days.

All specimens were analyzed at the Service of Pathological Anatomy of our Department.

The pieces were prepared according to the methodology below:

1) $10 \%$ formol solution fixation for 24 hours.

2) $7.5 \%$ nitric acid solution decalcification for 24 hours.

3) Tissue processing using a histotechnical apparatus.

4) Three histological sections of each sample.

5) Hematoxylin-eosin staining.

The amount of osteoclasts, osteoblasts and vascular stromata, as well as the presence of immature and lamelar bone, was microscopically assessed. This analysis allowed us to evaluate criteria such as cell feasibility, vascularization, necrosis, bonematrix preservation, inflammatory process, bone remodeling, and the presence of fibrosis.

A statistical comparison was made of the quantitative and qualitative results obtained in Groups $A$ and B, using Fisher's t test. The results with $p<0.05$ were considered significant.

\section{RESULTS}

Twenty of the 40 specimens evaluated in the control Group A and 20 cryopreserved specimens from Group B provided the results below.

Control Group A maintained the cell feasibility at 100\% (20 of the 20 specimens evaluated), while the group that was kept frozen showed a cell feasibility of 70\% (14/20). According to Fisher's t- test, this gives $p=0.02$, indicating a significant inter group difference.

As to vascularization, the control group was $100 \%$ positive, while the cryopreserved group was $85 \%$ positive. According to Fisher's method, we found $p=0.231$, therefore no significant differences were shown as regards vascularization.

Further analysis showed the presence of necrosis in all specimens of both groups. According to Fisher's method, we found $p=1$, indicating that no significant differences occurred.

The analysis of bone-matrix preservation showed that 34 of the 40 specimens evaluated maintained their bone matrices: 19 (95\%) in the control group and 15 (75\%) in the cryopreserved group, with $p=0.182$, meaning that no statistical differences were 
no Grupo controle (95\%) e 15 no criopreservado (75\%), o que nos dá um $\mathrm{p}=0.182$, sem diferença estatística.

No item processo inflamatório, foram observados apenas 06 casos de positividade, 05 casos após criopreservação (25\%) e apenas 01 no grupo controle (5\%) tendo, portanto, $p=0.182$.

$\mathrm{Na}$ análise da remodelação óssea, esta se mostrou ausente em 12 espécimes do grupo criopreservado (65\%) e 13 do Grupo controle (60\%). Obteve-se então um $p=1$, insignificante estatisticamente.

Finalmente, quanto à fibrose, foi encontrada em apenas 9 dos 40 espécimes estudados, 05 no criopreservado (25\%), e 04 no Grupo controle (20\%). Assim, com $p=1$, sem diferença estatística também neste item.

Na Figura 1 estão representados os itens, em relação aos percentuais para cada Grupo estudado.

\section{DISCUSSÃO}

O enxerto ósseo homólogo humano, vem desempenhando papel importante na cirurgia ortopédica reconstrutiva. Sendo assim, é imprescindível o completo conhecimento de suas propriedades biomecânicas e histológicas, para que o armazenamento, processamento e utilização possam ser feitos de forma adequada ${ }^{(3,7,10)}$

O congelamento retarda a autólise causada pela liberação de enzimas proteolíticas, influenciando assim, as condições do meio ambiente celular ${ }^{(6,9)}$

Nos dados obtidos a necrose óssea esteve presente em todos os cortes analisados, o que leva a crer ser conseqüência do processo de degeneração natural dos cadáveres (embora conservados a $4{ }^{\circ} \mathrm{C}$ ), já que as peças foram obtidas somente 48 horas após a morte dos doadores.

Considerando-se que a morte de um tecido não é determinada num evento estático (morte biológica do indivíduo), e sim uma seqüência de eventos ao nível celular, o estudo também avaliou nas peças anatômicas características concernentes aos tecidos vivos: a vascularização, a manutenção da matriz óssea, a presença de processo inflamatório, a fibrose e a remodelação óssea.

Nos espécimes criopreservados encontramos uma queda na qualidade da vascularização e da manutenção da matriz óssea, mas que não foram significativas estatisticamente. $O$ aloenxerto criopreservado teve $85 \%$ de preservação de sua vascularização, fato que pode viabilizar sua revitalização mais precocemente.

O processo inflamatório esteve mais presente após congelação, o que prova que mesmo após o resfriamento, eventos ao nível celular continuam acontecendo, mas também de maneira insignificante para a qualidade final dos enxertos. Não se found.

As to the inflammatory process, only 6 positive cases were found: 5 (25\%) cases after cryopreservation and only 1 (5\%) case in the control group, which gives us $p=0.182$.

An analysis of the bone remodeling showed that it was absent in 12 (65\%) specimens of the cryopreserved group and in $13(60 \%)$ specimens of the control group. This gives us $p=1$, which is not statistically significant.

Finally, fibrosis was found in only 9 of the 40 specimens studied: 5 (25\%) in the cryopreserved group and 4 (20\%) in the control group. This gives us $p=1$, that is, no statistical differences were found as regards fibrosis.

Figure 1 presents each one of the above-mentioned items as a function of the percentages found in each group studied.

\section{DISCUSSION}

Human allografts play an important role in reconstructive orthopedic surgery. Therefore, a full knowledge of their biomechanical and histologic properties is fundamental so that their storage, processing and utilization may be performed in a proper manner $(3,7,10)$.

The freezing process delays the autolysis caused by proteolytic enzymes release, thus influencing the conditions of the cell environment ${ }^{(6,9)}$.

Our data showed that bone necrosis was present in all sections analyzed, which leads us to the conclusion that necrosis is a consequence of the natural degeneration process found in cadavers (even when kept at $4^{\circ} \mathrm{C}$ ), since the specimens were obtained at 48 hours of the donors' death.

Considering that the death of a tissue is not determined within a static event (biological death of the individual), being rather a sequence of events at cell level, the study has also evaluated in the anatomical specimens a series of characteristics related to living tissues, such as vascularization, bone-matrix preservation, presence of inflammatory process, fibrosis, and bone remodeling.

In the cryopreserved specimens we found a decline in the quality of vascularization and bone-matrix preservation, although not statistically significant. The vascularization in the cryopreserved allografts was $85 \%$ preserved, a fact that might make its revitalization feasible earlier.

The inflammatory process showed to be more present after the freezing process, proving that, even after cooling, events at cell level will continue to happen, although with no significance in the final quality of the grafts. No differences were noticed between groups as regards bone remodeling and the presence of fibrosis.

The only histological aspect to show a change in statistical significance was cell feasibility, which decreased after cryopre- 
observaram diferenças entres os Grupos no que diz respeito à remodelação óssea e presença de fibrose.

O único aspecto histológico que mostrou alteração de significância estatística foi à viabilidade celular, apresentando queda após a criopreservação. A viabilidade celular é definida pelo aspecto nuclear da célula, a presença de nucléolo e integridade da membrana nuclear.

Alterações de pH, tensão de oxigênio e liberação de citocinas que ocorrem durante a criopreservação interferem no equilíbrio celular e no material genético nuclear (DNA), alterando a morfologia e a viabilidade das células. Entendemos ainda que durante o processo de resfriamento, o efeito físico de expansão de volume sofrido pela água, na faixa de temperatura que varia dos $4^{\circ} \mathrm{C}$ aos $0^{\circ} \mathrm{C}$ o que leva à lise celular.

Os aloenxertos ósseos são usados nas cirurgias ortopédicas reconstrutivas não só por suas propriedades osteoindutoras, mas principalmente as osteocondutoras. Assim, o arcabouço mineral ósseo preservado dos enxertos será preenchido por novos osteócitos do receptor após a osteointegração. Logo, a perda de viabilidade celular demonstrada por este estudo não contra-indica a utilização dos aloenxertos após criopreservação, pois os enxertos ósseos não dependem de células vivas para ter utilidade clínica e sim da matriz óssea, onde estão as proteínas morfogenéticas.

\section{CONCLUSÕES}

1. O congelamento ósseo a menos $80^{\circ} \mathrm{C}$ altera a viabilidade celular.

2. Não há diferença na vascularização, preservação da matriz, remodelação óssea e fibrose entre o congelamento ósseo a menos $80^{\circ} \mathrm{C}$ e o tecido a $4^{\circ} \mathrm{C}$

3. O processo de criopreservação, utilizado para o armazenamento dos enxertos homólogos humanos em bancos de tecidos, não altera suas qualidades de maneira que possa contra-indicar sua aplicação nas cirurgias ortopédicas.

\section{REFERÊNCIAS BIBLIOGRÁFICAS}

1 - Bauer TW, Muschler GF. Bone graft materials. An overview of the basic science. Clin Orthop 371:10-27, 2000

2 - Boyce T, Edwards J, Scarborough N. Allograft bone. The influence of processing on safety and performance. Orthop Clin North Am 30:571-581, 1999

3 - Burchardt H. The biology of bone graft repair. Clin Orthop 42:28-42, 1983

4 - Deijkers RL, Bouma GJ, van der Meer-Prins EM et al. Human bone allografts can induce T cells with high affinity for donor antigens. J Bone Joint Surg $\mathrm{Br}$ 81:538-544, 1999.

5 - Husted H, Kramhoft MU. Microbiology of femoral head grafts in bone banks. Ugeskr Laegen 158:6260-6262, 1996.

6 - Kakiuchi M, Ono K. Preparation of bank bone using defatting, freeze-drying and sterilization with ethylene oxide gas. Part 2. Clinical evaluation of its efficacy and safety. Int Orthop 20:147-152, 1996.

7 - Kerry RM, Masri BA, Garbuz DS, Czitrom A, Duncan CP. The biology of bone grafting. Instr Course Lect 48:645-652, 1999.

8 - Lewandrwski KU, Rebmann V, Passler M, et al. Immune response to perforated and partially demineralized bone allografts. J Orthop Sci 6:545-555, 2001. servation. Cell feasibility is defined by the cell's nuclear aspect, the presence of the nucleolus and the integrity of the cell membrane.

Changes in $\mathrm{pH}$, oxygen tension and cytokine release during the cryopreservation process will interfere in the cell balance and in the nuclear genetic material (DNA), altering the cell morphology and feasibility. Also, we believe that during the cooling process the physical effect of volume expansion that occurs in water at temperature range from $4{ }^{\circ} \mathrm{C}$ to $0^{\circ} \mathrm{C}$ leads to cell lysis.

Bone allografts are employed in reconstructive orthopedic surgeries, not only because of their osteoinductive properties, but also and mainly because of their osteoconductive properties. Therefore, the bone mineral structure that is preserved in grafts will be filled by new osteocytes of the receptor after osteointegration. Thus, the loss of cell feasibility shown by this study does not contraindicate the use of allografts after cryopreservation, since bone grafts do not depend on living cells to be clinically useful, but on the bone matrix, where morphogenetic proteins are located.

\section{CONCLUSIONS}

1. Bone freezing at minus $80^{\circ} \mathrm{C}$ changes cell feasibility.

2. There are no differences in vascularization, matrix preservation, bone remodeling and fibrosis between bone freezing at minus $80^{\circ} \mathrm{C}$ and the tissue at $4^{\circ} \mathrm{C}$.

3. The cryopreservation process employed in the storage of human allografts in tissue banks does not change their qualities to the extent of contraindicating their application in orthopedic surgeries.
9 - Matter HP, Garrel TV, Bilderbeek U, Mittelmeier W. Biomechanical examinations of cancellous bone concerning the influence of duration and temperature of cryopreservation. J Biomed Mater Res 55:40-44, 2001.

10 - Pelker RR, Friedlaender GE, Markham TC. Biomechanical properties of bone allografts. Clin Orthop 174:54-57, 1983.

11 - Sommerville SM, Johnson N, Bryce SL, Journeaux SF, Morgan DA. Contamination of banked femoral head allograft: incidence, bacteriology and donor follow up. Aust N Z J Surg 70:480-484, 2000

12 - Stevenson S. Biology of bone grafts. Orthop Clin North Am 30:543-552, 1999

13 - Sugihara S, van Ginkel AD, Jiya TU, van Royen BJ, van Diest PJ, Wuisman PI. Histopatology of retrieved allografts of the femoral head. J Bone Joint Surg Br 81:336-341, 1999.

14 - Tomford WW, Mankin HJ. Bone banking. Update on methods and materials Orthop Clin North Am 30:565-570, 1999.

15 - Yazdi M, Bernick S, Paule WJ, et al. Postmortem degradation of demineralized bone matrix osteoinductive potential: effect of time and storage temperature. Clin Orthop 262:281-287, 1991. 